\title{
Education and Socio-Economic Differentials: A Study of School Performance in the Western Cape
}

\author{
Servaas van der Berg \\ Stellenbosch University \\ E-mail:SVDB@sun.ac.za
}

Ronelle Burger

Stellenbosch University

E-mail: rburger@sun.ac.za 


\section{Abstract}

Not surprisingly, the education system is widely perceived to be the major tool to overcome human capital and labour market inequalities in South Africa. This paper asks how well the education system accomplishes this goal.

The first part of the paper examines human capital differentials between races and provides evidence of persistent race-based educational attainment and quality differentials. It is argued that quality differentials in education may be much larger and more enduring than attainment differentials.

The second part of the paper asks whether the deficiency lies in inadequate resource availability in schools of the poor or whether it rather stems from inefficiencies in parts of the school system. This also relates to an important debate in the international economics of education literature, viz. to what extent school resources matter.

The paper uses national and Western Cape matriculation results and resource allocation data to examine this question and find that residuals are higher in predominantly black and coloured schools and there is no significant correlation between performance and resource allocation in this group of schools. If the residual is seen as a proxy for the impact of omitted variables like efficiency, these phenomena can be interpreted as evidence that without the required efficiency improvements, resource shifts are unlikely to have the desired impact on race-based differentials in the quality of schooling, and also through the latter's association with labour productivity racebased differences in employment and earnings.

\section{Acknowledgements}

We would like to thank Shireen Motala, who commented on an earlier draft of the paper.

Development Policy Research Unit

Tel: +27 216505705

Fax: +27 216505711
Information about our Working Papers and other published titles are available on our website at: http://www.commerce.uct.ac.za/DPRU 


\section{Table of Contents}

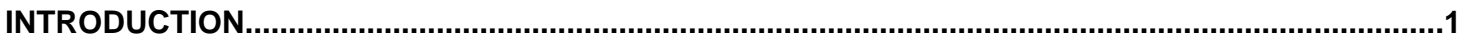

A. CONSIDERING TRENDS IN HUMAN CAPITAL DIFFERENTIALS...................................................

1. RELATIONSHIP BETWEEN EDUCATION AND EARNINGS.........................................................

2. RACE-BASED DIFFERENTIALS IN EDUCATION ATTAINMENT...................................................3

3. EDUCATION SPENDING AND RACE-BASED EDUCATION QUALITY DIFFERENTIALS.................3

4. EDUCATION QUALITY AND SOCIO-ECONOMIC DIFFERENTIALS..............................................5

B. RESOURCE ALLOCATION AND EFFICIENCY AS DETERMINANTS OF SCHOOL

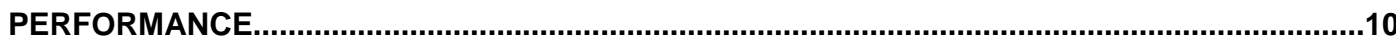

1. COMPARING WESTERN CAPE SCHOOL PERFORMANCE TO NATIONAL DATA.........................10

2. EXAMINING SCHOOL PERFORMANCE IN WESTERN CAPE....................................................13

2.1 FULL-SAMPLE MODELS EXAMINING DETERMINANTS OF OVERALL MATHEMATICAL PERFORMANCE OF SCHOOLS IN THE WESTERN CAPE.

2.2 RACE-BASED MODELS EXAMINING DETERMINANTS OF OVERALL PERFORMANCE IN

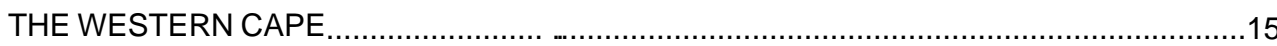

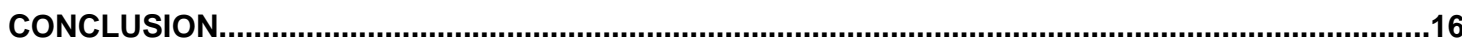

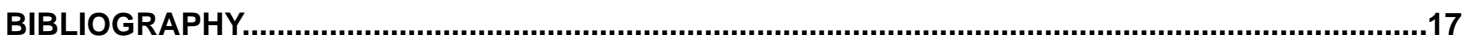

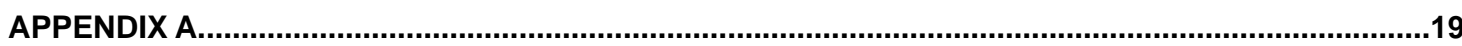

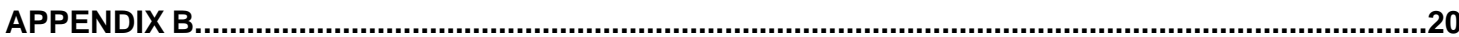




\section{Introduction}

In a highly unequal society in which labour market inequalities largely have their origin in human capital differentials, it is not surprising that the educational system is seen as a major tool to overcome these inequalities. Does the South African educational system accomplish this?

The first section of this paper will show that although human capital differentials are narrowing, it is happening slowly and there is still a considerable amount of inequality in the labour market.

The next section deals with the central question for this paper: to what extent persistence in school quality inequalities is attributable to resource allocation and to what extent it is attributable to differences in efficiency of resource use. This also relates to an important question of debate in the international economics of education literature, viz. to what extent resources matter in schools. In this paper efficiency will be used to refer to the ratio of resources invested to outcomes. In schools this can often be equated with managerial efficiency, as efficiency in schools is mostly dependent on the school's incentive frameworks and the managerial skills of decision makers.

This paper builds on previous work by one of the authors (Van der Berg 2001a \& 2002) For most schools in six of the provinces the author linked school performance as measured by matriculation pass rate to socio-economic background as measured by school fees and to inputs of teaching resources.. The disturbing conclusion from that work was that the South African school system appears to still perform much as it did under apartheid: predominantly black schools although now better resourced have not improved their matriculation output in quantitative (and indeed also qualitative) terms, whilst predominantly white schools now less privileged in terms of teaching resources and containing more pupils from other race groups are still performing as well as in the past. Thus, differentials between schools are largely unchanged, although the racial edge to the inequality has been reduced through the opening up of formerly white schools.

To move the analysis for this paper beyond the scope of the two earlier papers, we narrowed the geographical focus to the Western Cape to obtain a more recent and larger set of variables with more detailed information on matriculation results. It is also hoped that this paper will contribute to the growing attention by economists to issues of South African education.

We start off by looking at the convergence rate for human capital differentials.

\section{A. Considering Trends in Human Capital Differentials}

\section{Relationship Between Education and Earnings}

The growing earnings function literature in South Africa and internationally shows a tight relationship between education and labour market status and earnings. This is also illustrated by Figure 1, which shows that the small number of relatively well-educated adults (e.g. those with a degree), are concentrated at the upper end of the expenditure distribution. At least for 1995, a degree acted as an important guarantee of being near the top of the expenditure ladder. 


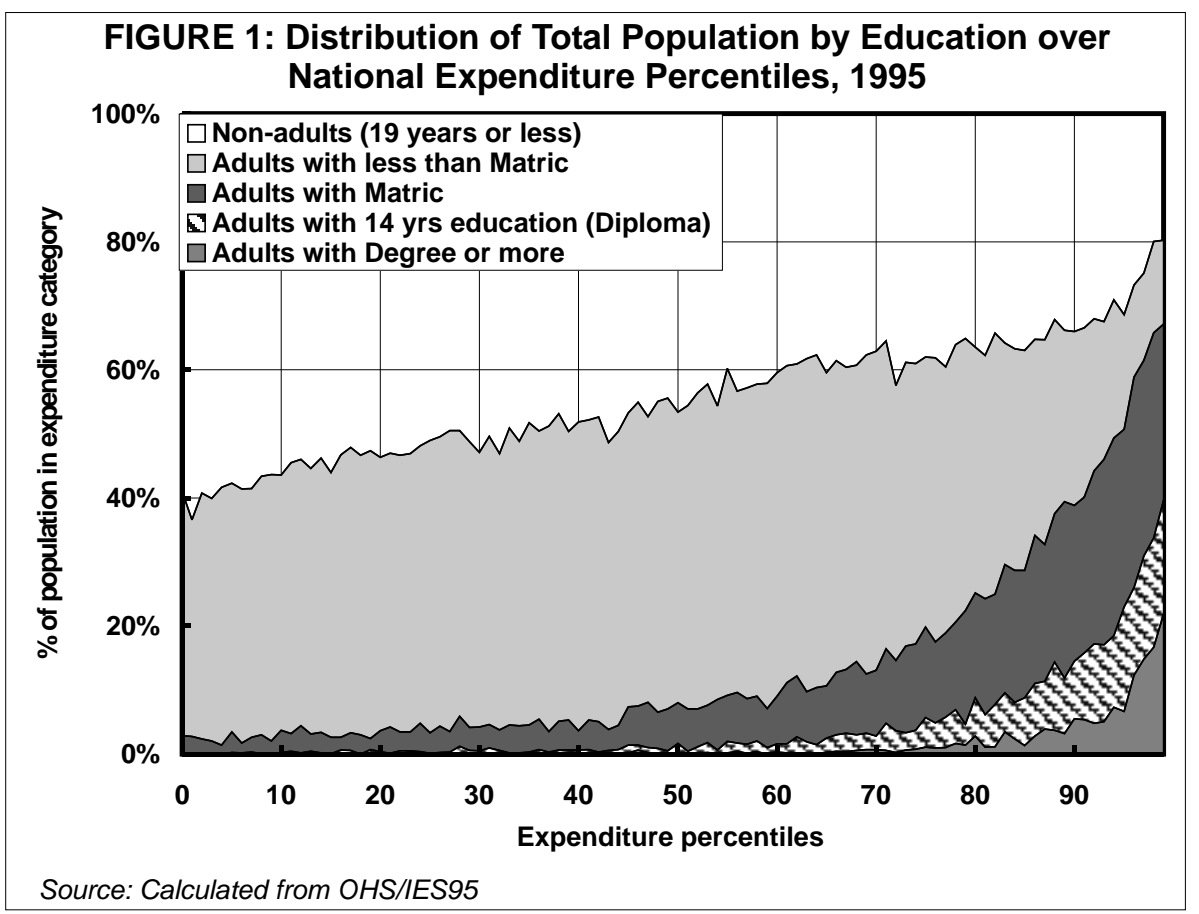

Another way of considering this data is presented in Table 1, which shows that adults with degrees constitute only 1.6 percent of the total South African population, yet they are 10 percent of the population in the top decile. By contrast, adults with less than Matric are scarce in the higher rungs of the expenditure distribution.

\begin{tabular}{|c|c|c|c|c|c|c|}
\hline \multicolumn{7}{|c|}{$\begin{array}{l}\text { Table 1: Share of Non-adults and Adults in Various Educational Categories } \\
\text { in the Population and in the Various Expenditure Categories, } 1995\end{array}$} \\
\hline Sharein: & Non-adults & \begin{tabular}{|c|}
$\begin{array}{c}\text { Adults with } \\
\text { less than } \\
\text { Matric }\end{array}$ \\
\end{tabular} & \begin{tabular}{|c} 
Adults with \\
Matric
\end{tabular} & \begin{tabular}{|c} 
Adults with \\
Diploma \\
(14 yrs)
\end{tabular} & \begin{tabular}{|c|} 
Adults with \\
Degree or \\
more
\end{tabular} & \begin{tabular}{|c|}
$\begin{array}{c}\text { Total } \\
\text { Population }\end{array}$ \\
\end{tabular} \\
\hline Total Population & $44.0 \%$ & $40.8 \%$ & $10.0 \%$ & $3.2 \%$ & $1.6 \%$ & $100.0 \%$ \\
\hline Poorest 20\% (Quintile 1) & $56.3 \%$ & $40.4 \%$ & $2.6 \%$ & $0.2 \%$ & $0.0 \%$ & $100.0 \%$ \\
\hline Poorest 40\% (Quintiles $1 \&$ 2) & $53.4 \%$ & $42.5 \%$ & $3.2 \%$ & $0.3 \%$ & $0.0 \%$ & $100.0 \%$ \\
\hline Quintile 2 & $50.5 \%$ & $44.6 \%$ & $3.8 \%$ & $0.4 \%$ & $0.1 \%$ & $100.0 \%$ \\
\hline Quintile 3 of SA Population & $45.1 \%$ & $47.3 \%$ & $5.9 \%$ & $0.9 \%$ & $0.2 \%$ & $100.0 \%$ \\
\hline Quintile 4 of SA Population & $38.3 \%$ & $46.5 \%$ & $11.1 \%$ & $2.9 \%$ & $0.6 \%$ & $100.0 \%$ \\
\hline \begin{tabular}{|l|} 
Richest $20 \%$ \\
(Quintile 5, Deciles 9 \& 10) \\
\end{tabular} & $31.6 \%$ & $26.2 \%$ & $24.8 \%$ & $10.5 \%$ & $6.4 \%$ & $100.0 \%$ \\
\hline Richest 10\% (Decile 10) & $28.2 \%$ & $19.2 \%$ & $28.5 \%$ & $13.5 \%$ & $10.0 \%$ & $100.0 \%$ \\
\hline
\end{tabular}




\section{Race-based Differentials in Educational Attainment}

South African human capital differentials as measured by educational attainment data from the 1996 Census and various October Household Surveys (OHS) have been narrowing in the past few decades. This has been remarked upon by, amongst others, Lam (1999), who contrasts the narrowing racial educational attainment gap as measured by years of education completed in South Africa with that in Brazil, where progress has been much slower. Thus at least on the surface, it appears that inequality is declining. Some of the descriptive analysis that follows and previous research (Van der Berg et al. 2002) illustrate that the picture is more complicated than that because quality differentials in human capital may be much larger and more enduring than attainment differentials.

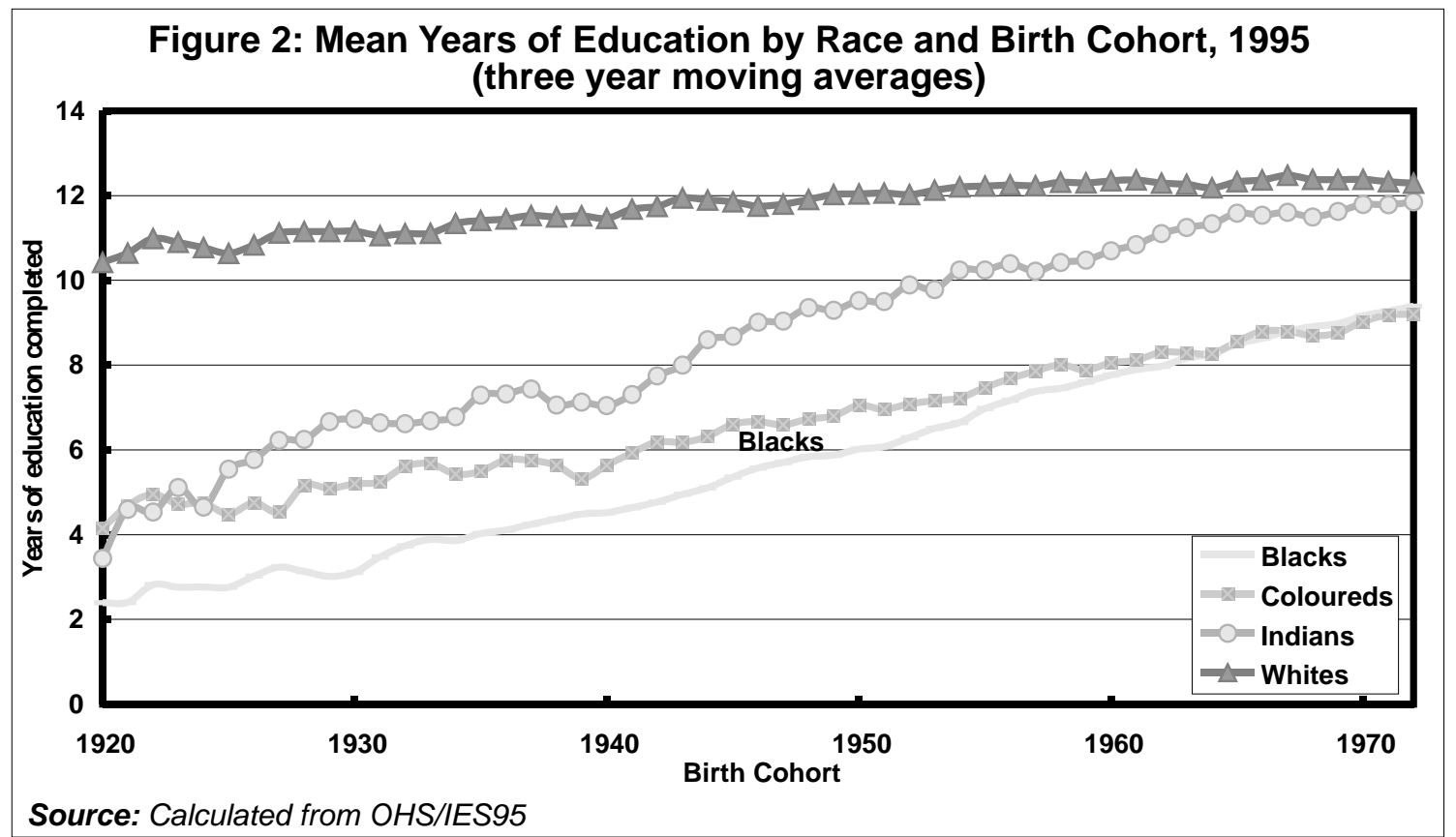

\section{Education Spending and Race-based Education Quality Differentials}

South African education already takes a large share of national resources, placing South Africa at or near the top of the international league in terms of proportion of national resources (GDP) devoted to education spending. Since the transition to democracy, resources devoted to school education have increased considerably and large resource shifts have taken place to poorer schools (Van der Berg 2001b), yet outputs of successful matriculants or of those matriculating with university exemption are stagnating or declining (Figure 3). There seems to be a poor conversion of inputs into educational outputs, i.e. in numeric terms educational outputs are only weakly related to educational resources though a time lag between resource shifts and changes in outcome may partly account for this. 


\section{Figure 3: Matriculation Passes and Exemptions, South Africa 1988-2001}

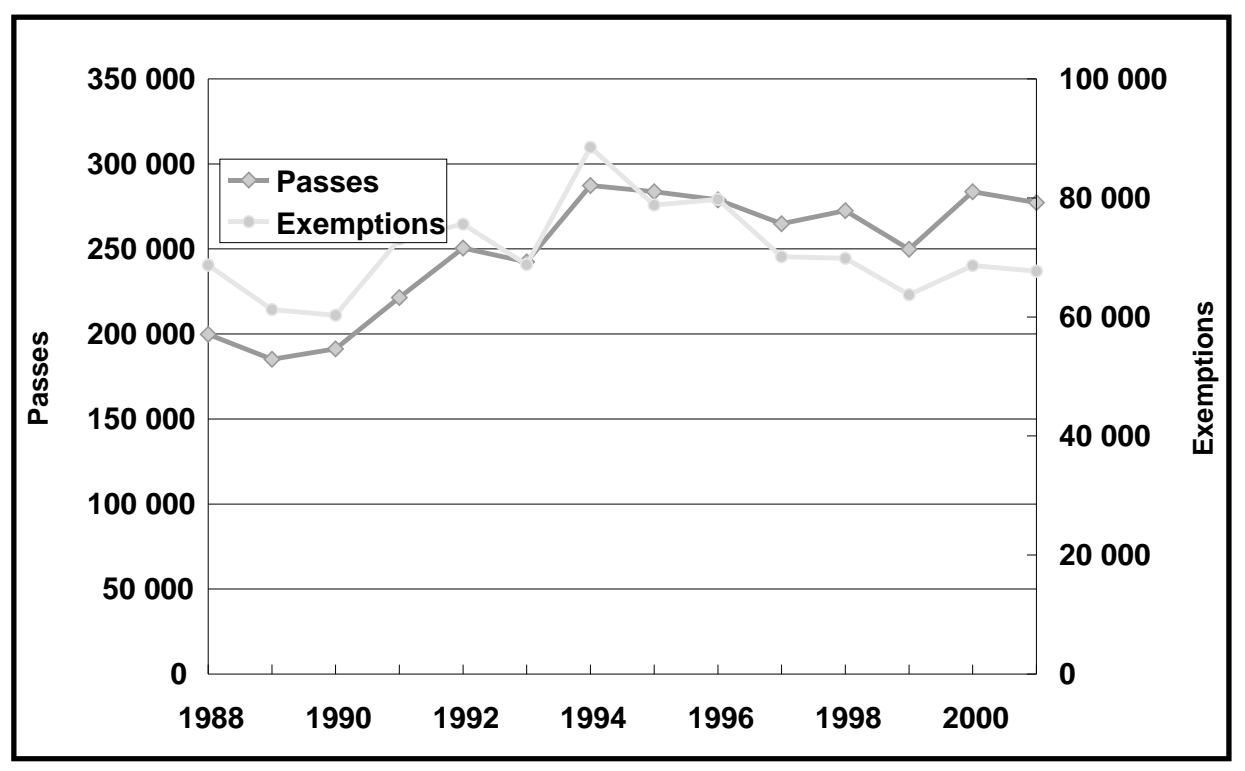

Source: RIEP 2001 \& Website of Department of Education

Much of the national problems also apply at the provincial level in the Western Cape, even though the province performs by far the best in terms of matriculation results. The Western Cape pass rate ( 82.7 percent) and exemption rate (25.0 percent) in 2001 were well above the national average (15.1 percent and 61.7 percent respectively). From 1994 to 2001 the Western Cape increased its share of national matriculation passes from 8.9 to 11.2 percent, and of exemptions from 9.9 to 13.9 percent, even though the province's performance in this regard was not spectacular (see Figure 4). Even more than at the national level, access to schools is no longer a major problem, as census and survey data show that virtually all children of school-going age are at school, at least to about age 15 or 16.

Figure 4: Matriculation Passes and Exemptions, Western Cape 1994-2001

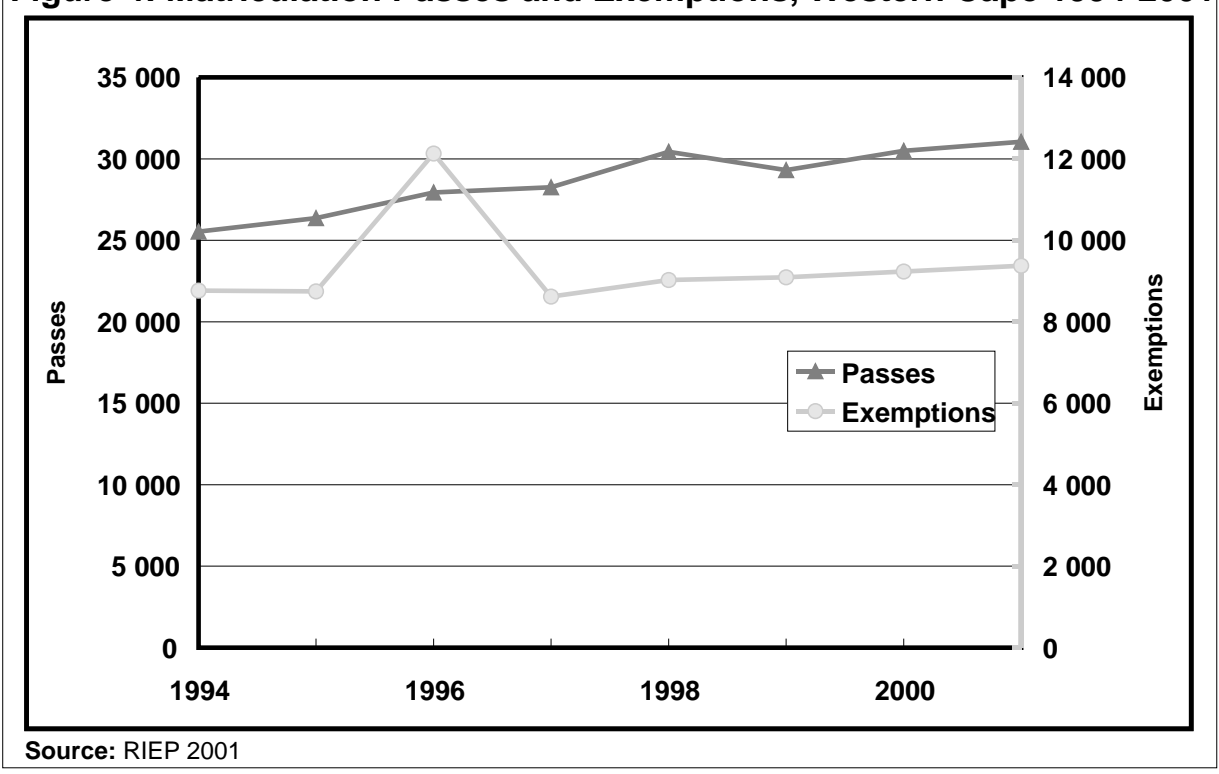




\section{Education Quality and Socio-Economic Differentials}

Serious quality problems with output of the educational system are apparent from poor performance in international tests, high matriculation failure rates (indicating lenient promotion policies at lower educational levels may be a problem) and by a small minority of matriculants electing to do subjects such as Science and Mathematics that are fundamental to further technical education that the labour market requires. Even the Western Cape's educational performance is far from ideal. This is well illustrated by the MLA Numeracy Test carried out in 1995 at the Grade 4 level in all provinces and in various African countries (Figure 5). Although the Western Cape performed best of all South Africa provinces and far better than the worst (Mpumalanga also shown in the graph), its performance was only marginally better than two of the participating African countries, and worse than the other nine.

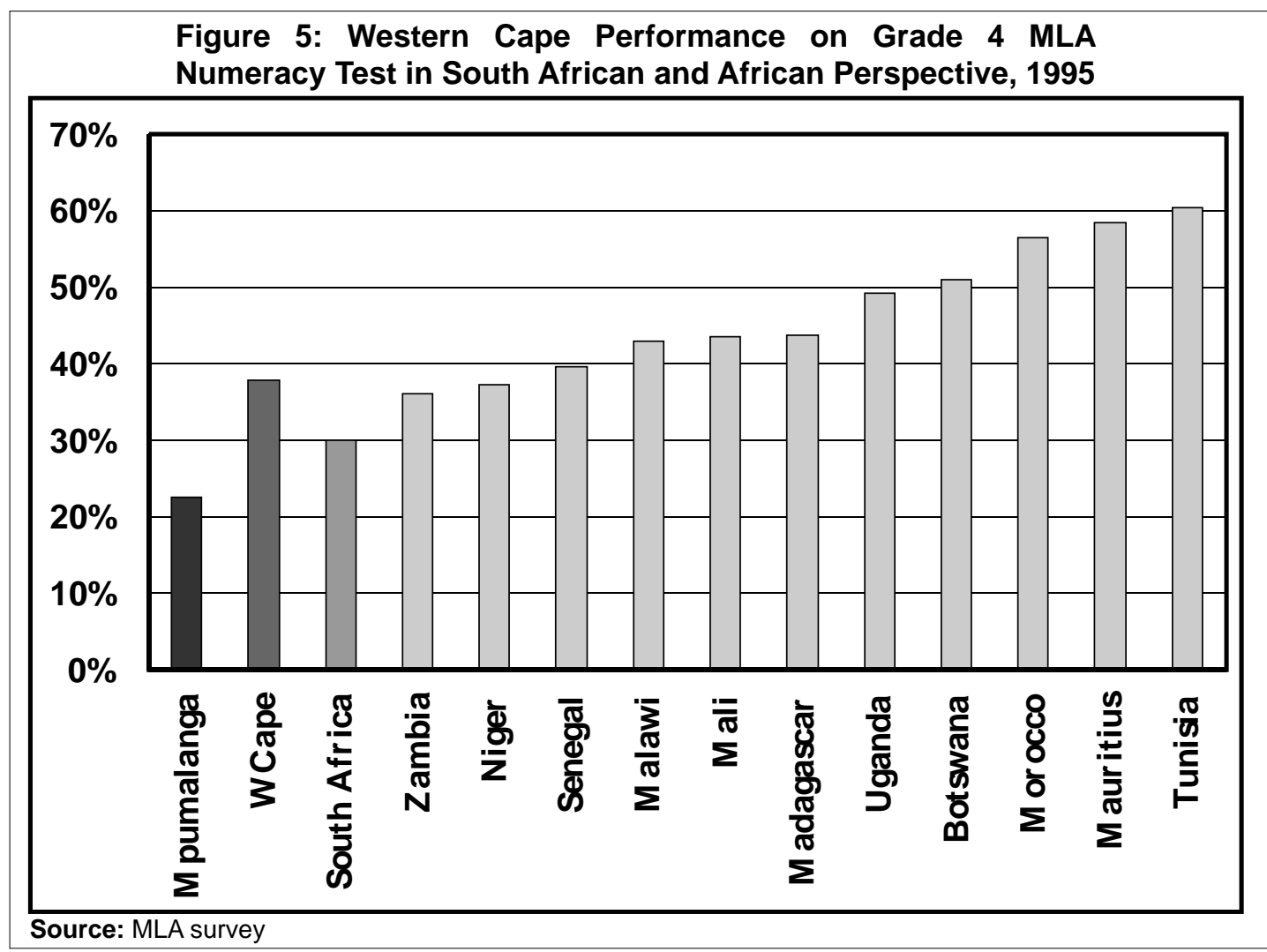

What is disturbing is that low educational attainment and quality seem to be associated with socioeconomic background and race.

Figure 6 shows that for the Western Cape, amongst 20-24 year olds still resident with parents at the time of the 1996 census, only 25 percent had matriculated in cases where the parent head of household had attained less than Grade 10 . This rises to 44 percent where the parent had reached Grades 10 or 11 , to 78 percent where the parent had matriculated and to 87 percent where the parent had a degree. Nationally, a similar pattern holds, as the figure shows. Clearly, parent education matters a great deal. 


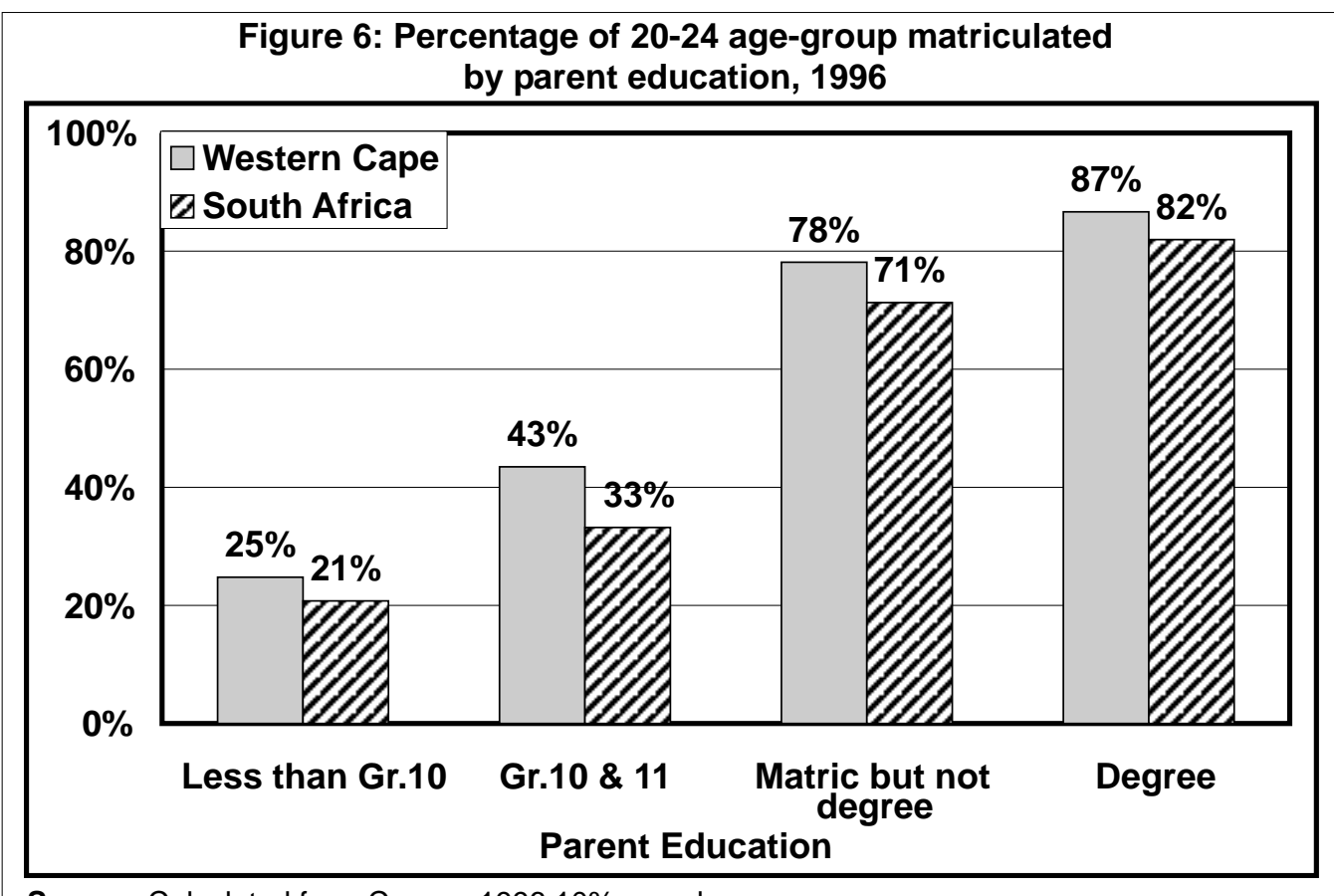

Source: Calculated from Census 1996 10\% sample

Within the Western Cape, the effect of past patterns of privilege is still severely felt. Figure 7 shows that predominantly white schools still outperform others, and that very few A-aggregates (a measure of quality) were obtained in other schools. Even university exemptions, another less restrictive measure of quality, were highly concentrated in predominantly white schools. Of the almost 6000 university exemptions in 1997, more than 60 percent were from predominantly white schools, versus only 2.5 percent from predominantly blacks schools. Thus entrance into

Figure 7: School "Race-type" by Matriculation Results, Western Cape 1997

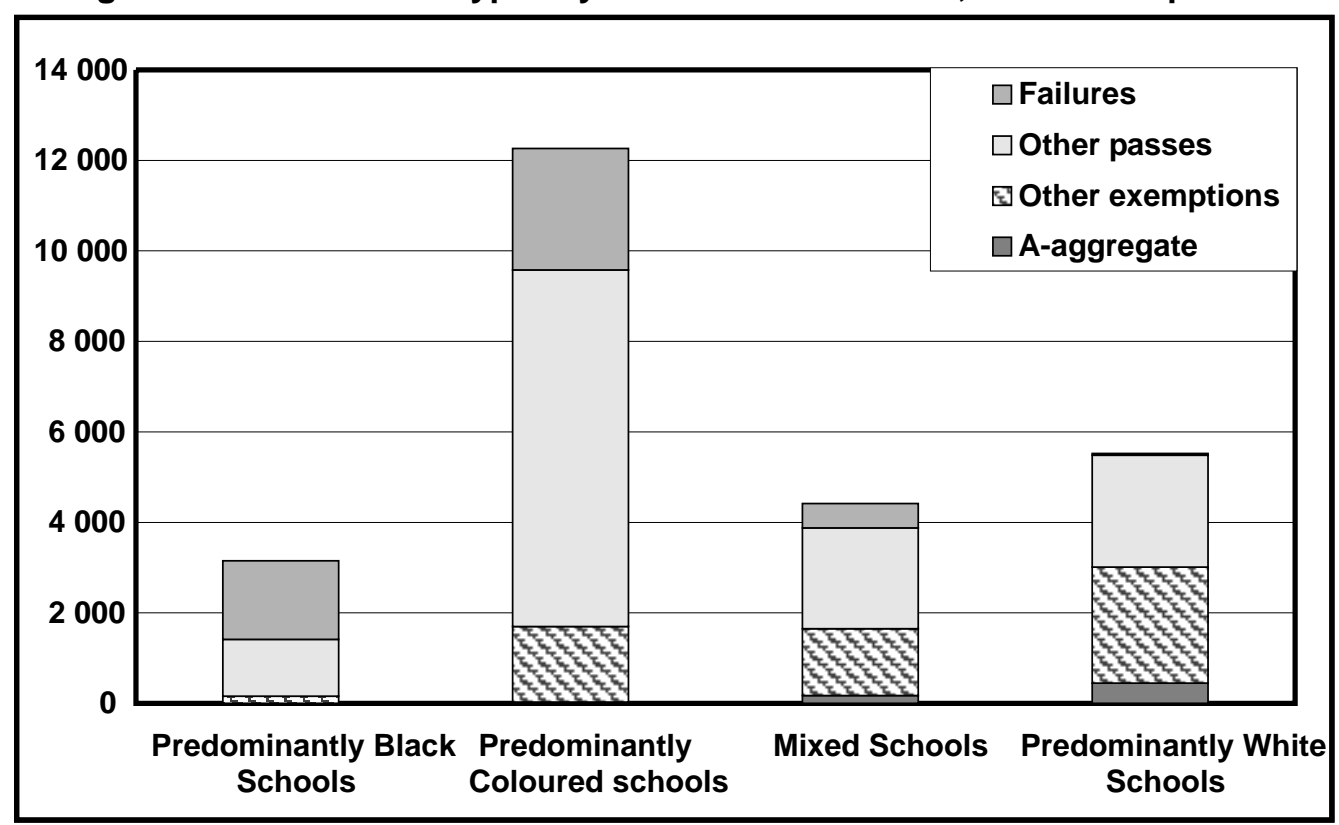

Source: Calculated from Western Cape Education Department Data 
universities perpetuates past patterns of privilege, and even more so if subject choice and performance at school are also considered (as discussed later). Failure rates are highest in predominantly black schools (53 percent).

If socio-economic background as reflected in school fees is considered, a similar picture emerges. A-aggregate performances and university exemptions are very scarce in schools at the bottom of the socio-economic rung, and A-aggregates especially are concentrated in schools with fees above R1 000 per year, to which few poor children have access.

\section{Figure 8: Matriculation Results by School Fee Category, Western Cape 1997}

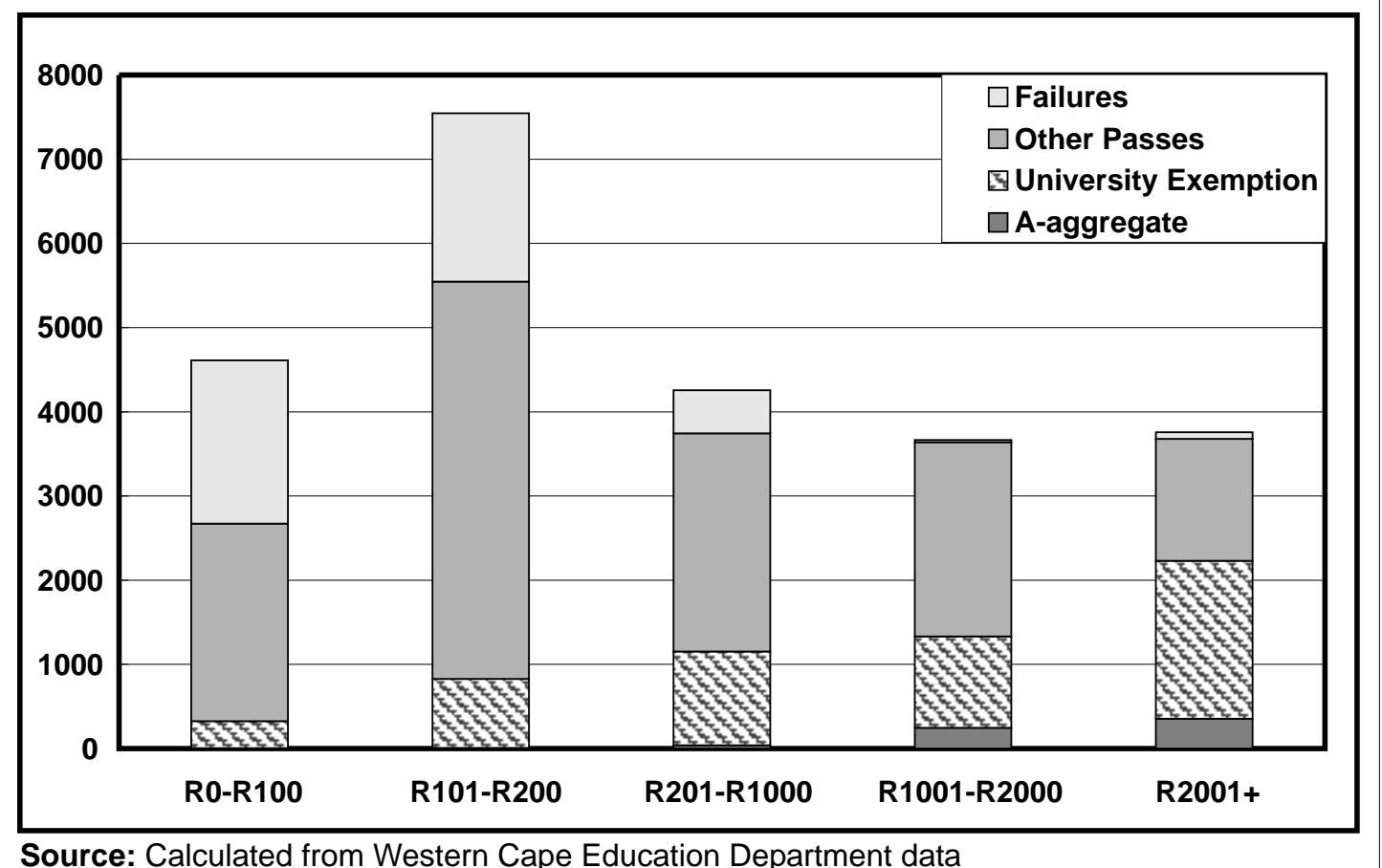

Source: Calculated from Western Cape Education Department data

The patterns are quite similar with respect to performance in Mathematics, a critical subject for further education. As can be seen, a surprisingly large proportion of pupils even amongst more affluent schools elect not to do Mathematics or to take it at the Standard Grade, thus closing the door on possible further studies in the Natural Sciences, Engineering, Medicine, Commerce and some other fields. Of the just over 2000 pupils who passed Mathematics at the Higher Grade in 1997, 80 percent were from schools with school fees above R1 000, and a slightly higher proportion, 83percent, from predominantly white schools. In contrast, only 20 pupils (1percent of the total) from predominantly black schools passed Mathematics at the Higher Grade. 
Figure 9: Mathematics Rresults by School Fee Category, 1997

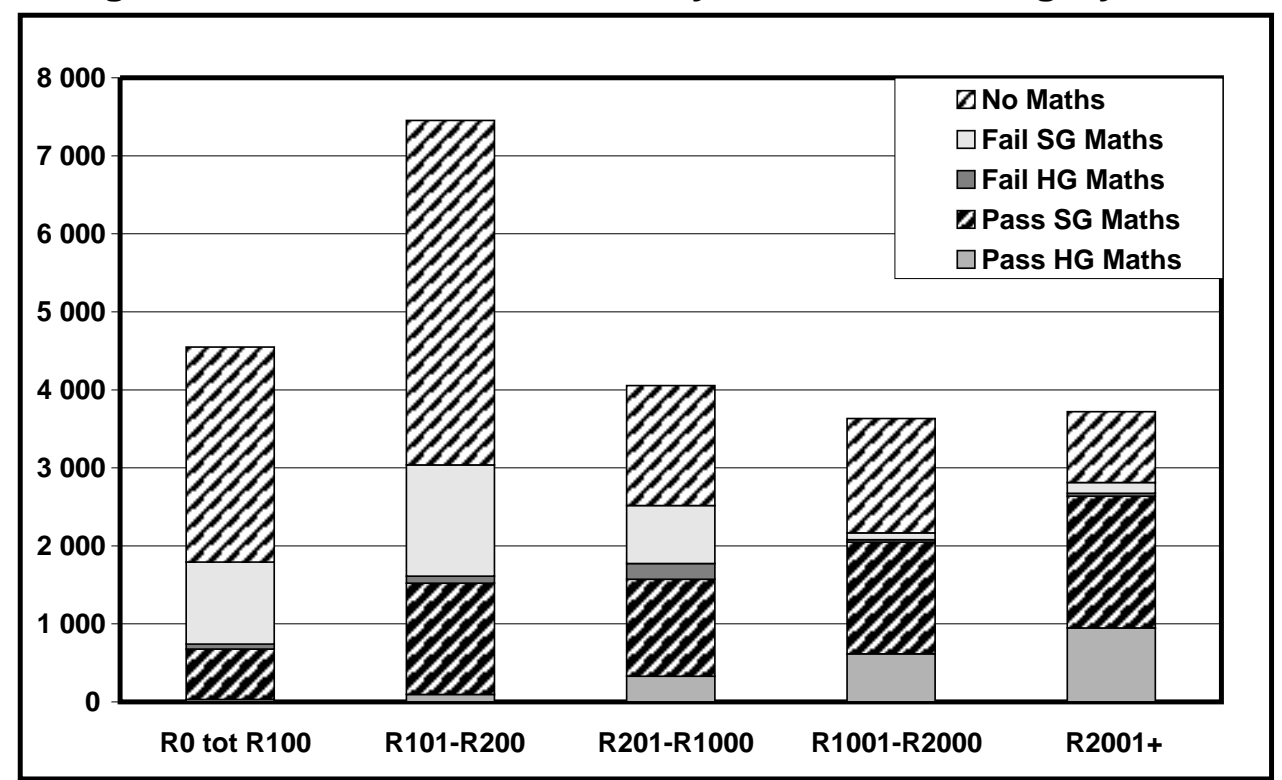

Source: Calculated from Western Cape Education Department Data

In the Western Cape as well as nationally, the problem of poor aggregate educational performance is mainly one of inadequate performance in a large part of the school system that has historically been neglected. However, within the same category of schools, many perform quite well. Figure 10 shows that many very poor predominantly black schools in the six provinces covered in terms of matriculation pass rates, but in the vast majority (71percent) of such schools, more than half of all pupils failed matriculation.

Figure 10: Frequency distribution of pass rates amongst predominantly black schools with fees of R30 or less, 1999-2000

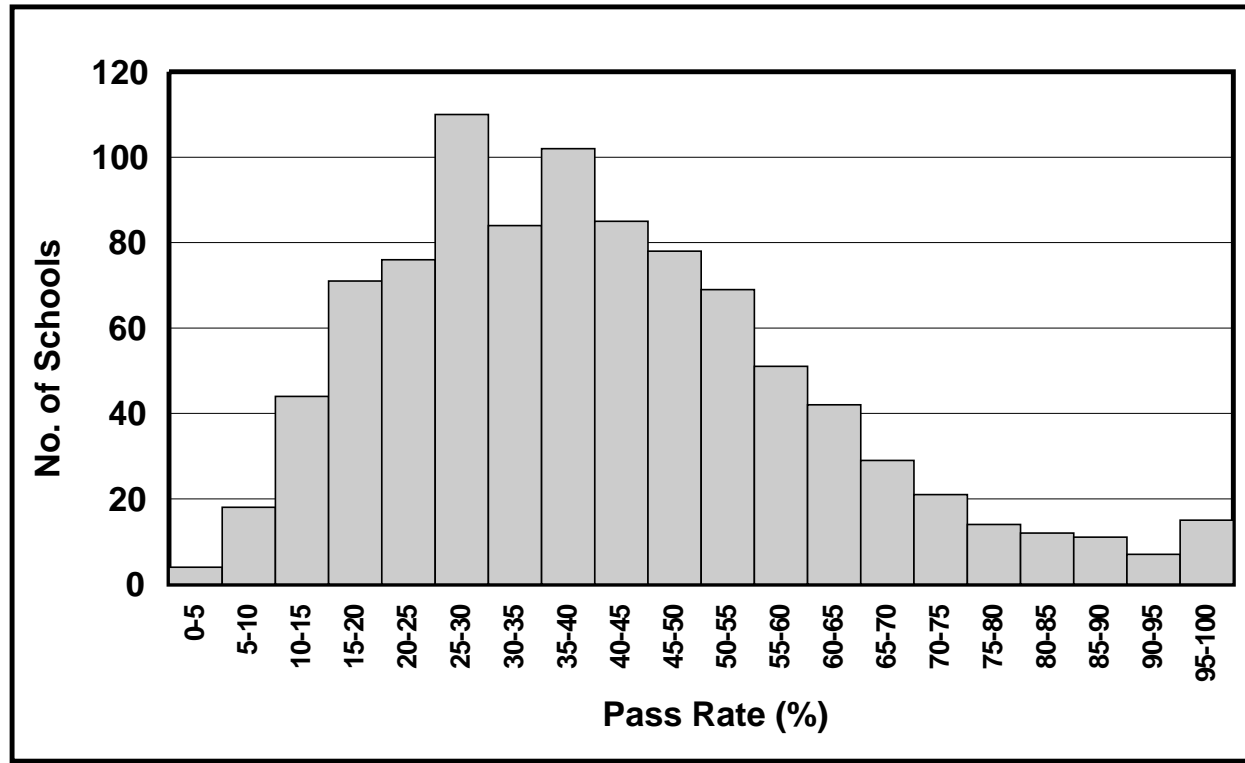

Source: Calculated from Department of Education Data 
Figure 11 shows the 37 Western Cape schools which in 1997 were all poor in terms of having school fees below R100; all were serving mainly the historically disadvantaged, with similar poor resources and similar levels of past neglect. Yet performance varied dramatically, as the figure shows. Nine of these schools even had pass rates that exceeded the provincial average (shown by the upper horizontal line; the lower black line shows the average pass rate for such poor schools).

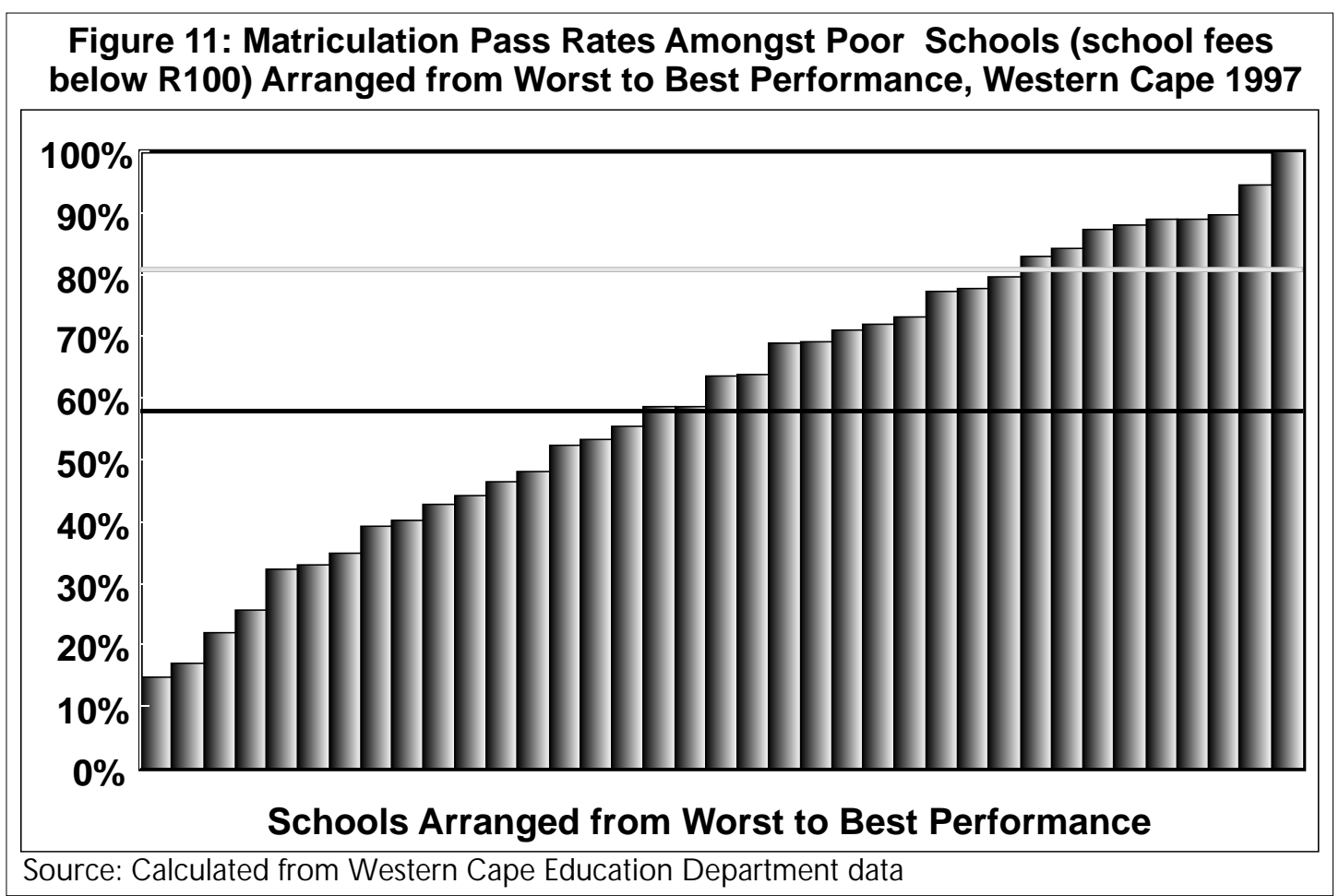

The next section will consider a range of different explanations for this variation in performance within socio-economic groups, examining school performance's empirical relationship with resource investments and the efficiency in the use of resources. 


\section{B. Resource Allocation and Efficiency as Determinants of School Performance}

The descriptive analysis in Section A accentuates the need to understand what is happening at school level in order to get a grip on likely future trends with regard to socio-economic differentials in the labour market. Even though useful, a perspective at the level of individual or samples of schools is inadequate. What is required is a systematic and quantitative perspective of school level performance.

It is notoriously difficult to obtain school level data in an attempt to measure school performance in a developing country context. We had at our disposal two datasets, pieced together from data provided by the various Departments of Education:

- The first dataset contains data from most schools in six provinces (the excluded provinces are Eastern Cape, Mpumalanga and North West). It relates to a few school level variables for 1997, and matriculation pass rates for 1999 and 2000. Because there is a lag between inputs and outputs in the school system, and resource, as well as racial composition shifts are slow, the gap between 1997 and 1999/2000 was not regarded as serious. Indeed, previous analysis showed that the data performed well in terms of both representativeness and presenting systematic patterns of results. (Van der Berg, 2002)

- The second, more detailed school level dataset for the Western Cape allows for a deeper analysis, because more variables are available to measure resource allocation, socioeconomic background and school performance. Even though the Western Cape may be atypical in that Matric pass ratios are considerably higher than elsewhere, patterns of differentials in performance between efficient and inefficient schools are likely to be similar as for South Africa as a whole.

We analyse these datasets in an attempt to better understand school level performance in the Western Cape. Based on previous research, we hypothesise that schools in poor communities do not overcome human capital backlogs on any appreciable scale, due to a combination of inadequate resources and inefficiency of resource use in poor schools. Thus we set out to evaluate after standardising for socio-economic background to what extent school performance amongst Western Cape schools is determined by availability of resources or what part is rather to be explained by inefficiency of resource use. The latter cannot be measured directly, but can be inferred mainly from the nature and magnitude of the residual that part of school performance not accounted for by socio-economic background or resources.

The next section will examine empirical relationships of school performance with socioeconomic indicators and resource investments on a national level, using the first dataset. The focus will be on the position of the Western Cape in the national sample.

\section{Comparing Western Cape School Performance to National Data}

Table 2 shows five regressions based on the first dataset. The first regression demonstrate that the performance of schools, as measured by matriculation pass rates is influenced by the socioeconomic background of pupils (measured by school fee levels), by the availability of teachers (pupil-teacher ratio), by teacher quality (as reflected in their average salary levels), and by the racial composition of schools. Racial composition can be interpreted as reflecting the continued effect of history on school performance. Thus, predominantly black schools the omitted or reference group still appear to be functioning comparatively poorly, even after controlling for their lower socio-economic background and higher pupil-teacher ratios. 
The second regression in Table 2 shows that, after allowing for the effect of other influences on school results, including racial composition of schools, the Western Cape outperforms equivalent schools nationally by almost 8 percentage points. The third regression tries to identify the source of the improved performance by using interaction effects. It finds that predominantly coloured schools in the Western Cape outperform the national average for similar schools by 10.1 percentage points, and white schools by 6.7 percentage points, although the statistical relationship is weaker in the latter case. Statistically Black schools in the Western Cape did not perform significantly better than schools nationally.

\begin{tabular}{|c|c|c|c|c|c|}
\hline \multicolumn{6}{|c|}{$\begin{array}{c}\text { Table 2: Regressions showing Western Cape schools } \\
\text { within the national sample } \\
\text { (dependent variable= Pass rate) (t-values in parentheses) }\end{array}$} \\
\hline & Equation 1: & Equation 2: & Equation 3: & Equation 4: & Equation 5: \\
\hline School Fees per Pupil & $\begin{array}{c}.012775^{\star \star \star} \\
(11.9 \\
\end{array}$ & $\begin{array}{c}.0131657^{\star \star \star} \\
(12.31) \\
\end{array}$ & $\begin{array}{c}.013277^{\star \star \star} \\
(12.33 \\
\end{array}$ & $\begin{array}{c}.013725^{* * *} \text { * } \\
12.31\end{array}$ & $\begin{array}{c}.013142^{\star \star \star} \\
(123)\end{array}$ \\
\hline Pupil-teacher Ratio & $\begin{array}{c}.10238^{* *} \\
(-2.56) \\
\end{array}$ & $\begin{array}{c}.1317211^{\star \star *} \\
(-3.27 \\
\end{array}$ & $\begin{array}{c}-.120385^{\star \star *} \\
(-2.980 \\
\end{array}$ & $\begin{array}{c}-.116283^{* *} \\
(-2.82) \\
\end{array}$ & $\begin{array}{c}0.04032 \\
(0.0 a) \\
\end{array}$ \\
\hline Teacher Salary & $\begin{array}{c}.000375^{\star \star \star \star} \\
(7.35\end{array}$ & $\begin{array}{c}.0003358^{\star \star \star} \\
(6.51)\end{array}$ & $\begin{array}{c}.0003496^{\star \star \star} \\
(6.76)\end{array}$ & $\begin{array}{c}.000336^{\star \star \star} \\
(6.5)\end{array}$ & $\begin{array}{c}.000332^{\star \star \star} \\
(6.43\end{array}$ \\
\hline \multicolumn{6}{|c|}{ School Race Composition: } \\
\hline $\begin{array}{l}\text { Dummy for Schools } \\
\text { with Predominantly } \\
\text { Coloured Pupils }\end{array}$ & $\begin{array}{c}27.8585^{\star \star \star} \\
(17.50)\end{array}$ & $\begin{array}{c}22.9404^{\star \star \star} \\
(12.00)\end{array}$ & $\begin{array}{c}20.9081^{\star \star \star} \\
(7.69)\end{array}$ & $\begin{array}{r}21.348^{\star \star \star} \\
(10.55)\end{array}$ & $\begin{array}{c}22.9615^{\star \star \star} \\
(12.11)\end{array}$ \\
\hline $\begin{array}{l}\text { Dummy for Schools } \\
\text { with Predominantly } \\
\text { Indian Pupils }\end{array}$ & $\begin{array}{l}29.1935^{\star \star \star} \\
\quad(12.03\end{array}$ & $\begin{array}{c}29.5404^{\star \star \star} \\
(12.21)\end{array}$ & $\begin{array}{l}28.9239^{\star \star \star} \\
(11.73\end{array}$ & $\begin{array}{c}29.4888^{\star \star \star} \\
(122)\end{array}$ & $\begin{array}{c}29.5804^{\star \star \star} \\
(12.23\end{array}$ \\
\hline $\begin{array}{l}\text { Dummy for Schools } \\
\text { with Predominantly } \\
\text { White Pupils }\end{array}$ & $\begin{array}{c}33.1466^{\star \star \star} \\
\quad(18.05\end{array}$ & $\begin{array}{c}32.5207^{\star \star \star} \\
(17.78\end{array}$ & $\begin{array}{l}32.2477^{\star \star \star} \\
\quad(16.95\end{array}$ & $\begin{array}{c}32.030^{\star \star \star} \\
(17.35\end{array}$ & $\begin{array}{c}32.5291^{\star \star \star} \\
(17.73\end{array}$ \\
\hline $\begin{array}{l}\text { Dummy for School } \\
\text { with No Predominant } \\
\text { Race Group (mixed) }\end{array}$ & $\begin{array}{l}23.0368^{\star \star *} \\
\quad(15.13\end{array}$ & $\begin{array}{l}22.8271^{* * *} \\
\quad(15.05\end{array}$ & $\begin{array}{c}23.0476^{\star \star *} \\
\quad(15.13\end{array}$ & $\begin{array}{c}22.663^{\star \star *} \\
(14.93\end{array}$ & $\begin{array}{c}22.8435^{\star \star \star} \\
15.06\end{array}$ \\
\hline $\begin{array}{l}\text { Dummy for Schools } \\
\text { Not Specifying Race } \\
\text { (other) }\end{array}$ & $\begin{array}{c}36.4631^{* \star *} \\
(193)\end{array}$ & $\begin{array}{c}30.6278^{* \star *} \\
(135)\end{array}$ & $\begin{array}{c}26.658^{\star \star \star} \\
(6.41)\end{array}$ & $\begin{array}{c}29.6339^{* \star \star} \\
(12.73\end{array}$ & $\begin{array}{c}30.3808^{\star \star \star} \\
(13.3)\end{array}$ \\
\hline $\begin{array}{l}\text { Dummy for Western } \\
\text { Cape }\end{array}$ & & $\begin{array}{c}7.55337^{\star \star \star} \\
(4.61)\end{array}$ & & & \\
\hline \multicolumn{6}{|l|}{ Interaction Effects: } \\
\hline $\begin{array}{l}\text { Western Cape \& } \\
\text { School Fees per Pupil }\end{array}$ & & & & $\begin{array}{c}-0.00509 \\
(-1.78) \\
\end{array}$ & \\
\hline $\begin{array}{l}\text { Western Cape \& } \\
\text { Pupil -teacher Ratio }\end{array}$ & & & & $\begin{array}{c}-0.28816 \\
(-1.88) \\
\end{array}$ & \\
\hline $\begin{array}{l}\text { Western Cape \& } \\
\text { Teacher Salary }\end{array}$ & & & & $\begin{array}{c}.000199^{\star \star *} \\
(3.34\end{array}$ & $\begin{array}{c}.0000804^{\star \star \star} \\
(4.71)\end{array}$ \\
\hline $\begin{array}{l}\text { Western Cape \& } \\
\text { Predominantly Black } \\
\text { School }\end{array}$ & & & $\begin{array}{r}2.2821 \\
(0.79\end{array}$ & & \\
\hline $\begin{array}{l}\text { Western Cape \& } \\
\text { Predominantly } \\
\text { Coloured School }\end{array}$ & & & $\begin{array}{c}10.1463^{\star \star \star} \\
(3.21)\end{array}$ & & $\begin{array}{c}19.473^{\star \star \star} \\
4.22\end{array}$ \\
\hline $\begin{array}{l}\text { Western Cape \& } \\
\text { Predominantly } \\
\text { Indian School }\end{array}$ & & & $\begin{array}{c}16.6925 \\
(1.46\end{array}$ & $\begin{array}{c}18.5979^{\star \star \star} \\
(4.01)\end{array}$ & \\
\hline $\begin{array}{l}\text { Western Cape \& } \\
\text { Predominantly White } \\
\text { School }\end{array}$ & & & $\begin{array}{r}6.7416 \\
(1.73\end{array}$ & & \\
\hline $\begin{array}{l}\text { Western Cape \& } \\
\text { Other School }\end{array}$ & & & $\begin{array}{c}11.9109^{\star \star} \\
(2.71)\end{array}$ & & \\
\hline Constant & $\begin{array}{l}15.057^{\star \star \star} \\
\text { (3.32 }\end{array}$ & $\begin{array}{c}19.1211^{\star \star \star} \\
(4.15)\end{array}$ & $\begin{array}{c}17.6977^{* * \star} \\
(3.84\end{array}$ & $\begin{array}{c}18.59787^{* \star \star} \\
(4.0 \pi\end{array}$ & $\begin{array}{c}19.473^{\star * *} \\
(4.22)\end{array}$ \\
\hline $\begin{array}{l}\text { Number of } \\
\text { Observations }\end{array}$ & 2770 & 2770 & 2770 & 2770 & 2770 \\
\hline $\mathbf{R}^{2}$ & 0.5565 & 0.5599 & 0.5601 & 0.5609 & 0.5600 \\
\hline Adjusted $\mathrm{R}^{2}$ & 0.5552 & 0.5584 & 0.5581 & 0.5591 & 0.5586 \\
\hline
\end{tabular}


Regression 4 demonstrates the impact of interaction effects between Western Cape location and measures of socio-economic background and teacher inputs. Here it is evident that, compared to other provinces, socio-economic status as measured by school fees has a somewhat smaller impact on performances in the Western Cape than nationally, although it is statistically not very significant. Also, the availability and quality of teachers seem to have a greater effect in the Western Cape than nationally (although for the pupil-teacher ratio the statistical significance is weak). Regression 5 continues this line of investigation by dropping the first two interaction effects and retaining only the quality of teachers, which again is highly significant.

\begin{tabular}{|c|c|c|}
\hline \multicolumn{3}{|c|}{$\begin{array}{c}\text { Table 3: Regressions of performance in Western Cape schools } \\
\text { (dependent variable= Pass rate) (t-values in parentheses) }\end{array}$} \\
\hline & Equation 1 & Equation 2: \\
\hline SchoolFees perPupil & $\begin{array}{l}.006641^{\star *} \\
(2.84)\end{array}$ & $\begin{array}{c}.006649^{* *} \\
(2.84)\end{array}$ \\
\hline Pupilteacher Ratio & $\begin{array}{c}-0.20486 \\
(-1.50)\end{array}$ & \\
\hline Teacher Salary & $\begin{array}{c}.000696 * * * \\
(3.96)\end{array}$ & $\begin{array}{c}.0006672^{* * *} \\
(3.81)\end{array}$ \\
\hline \multicolumn{3}{|l|}{ School Race Composition: } \\
\hline $\begin{array}{l}\text { Dummy for Schools with Predominantly Coloured } \\
\text { Pupils }\end{array}$ & $\begin{array}{l}26.7021^{* \star *} \\
(8.78)\end{array}$ & $\begin{array}{l}29.44939 * * * \\
(12.1)\end{array}$ \\
\hline $\begin{array}{l}\text { Dummy for Schools with Predominantly Indian } \\
\text { Pupils }\end{array}$ & $\begin{array}{l}39.2298^{* * *} \\
(4.58)\end{array}$ & $\begin{array}{l}41.97406^{* \star *} \\
(5.00)\end{array}$ \\
\hline $\begin{array}{l}\text { Dummy for Schools with Predominantly White } \\
\text { Pupils }\end{array}$ & $\begin{array}{c}36.9238^{* \star \star} \\
(8.32)\end{array}$ & $\begin{array}{l}40.12903^{\star \star \star} \\
(10.29)\end{array}$ \\
\hline $\begin{array}{l}\text { Dummy for School with No Predominant Race } \\
\text { Group (Mixed) }\end{array}$ & $\begin{array}{c}29.7553^{\star \star \star} \\
(6.71)\end{array}$ & $\begin{array}{c}31.7082^{* * *} \\
(7.47)\end{array}$ \\
\hline Dummy for Schools not Specifying Race (Other) & $\begin{array}{c}35.2716^{\star \star \star} \\
(10.90)\end{array}$ & $\begin{array}{c}37.8830^{* \star \star} \\
(13.86)\end{array}$ \\
\hline Constant & $\begin{array}{c}-7.63494 \\
(-0.46) \\
\end{array}$ & $\begin{array}{c}13.75238 \\
(-0.86)\end{array}$ \\
\hline Number of Observations & 239 & 239 \\
\hline $\mathbf{R}^{2}$ & 0.6728 & 0.6696 \\
\hline Adjusted $\mathbf{R}^{2}$ & 0.6614 & 0.6595 \\
\hline
\end{tabular}

Table 3 contains equations measuring the effect of the various variables referred to in table 2 in Western Cape schools only. Given smaller heterogeneity of experience within the Western Cape, it is not surprising that the coefficient of determination (adjusted R2) is much higher in this Table (in both cases 0.67 ) than in the equivalent (first) equation in Table 2 (in all five cases 0.56). This implies that about two-thirds of the variation in performance between schools in the province can be explained by variables reflecting socio-economic status, teacher resources and racial composition. It is noticeable from Equation 1 that the pupil-teacher ratio is not a statistically significant predictor of Matric performance, keeping all other factors constant, thus it is dropped in Equation 2.

From the national level dataset, the e analysis in table 3, with the aid of the few variables available, has thus shown that the Western Cape does perform better than nationally, given socioeconomic background, teacher resources, and racial composition. Coloured schools (mainly 
former House of Representatives schools) in particular fare somewhat better in the Western Cape than equivalent schools nationally. Within the Western Cape, too, the preliminary analysis has shown that school fees play less of a role than elsewhere, whilst teacher quality matters more, and the teacher-pupil ratio does not appear to be all that important. The latter may be, however, because the range is somewhat less than nationally.

In order to deepen our analysis of school performance in the Western Cape, we turn to an analysis of the second dataset.

\section{Examining School Performance in the Western Cape}

This Section examines differentials in the school performance of a sample of 247 high schools in the Western Cape with the aim of studying the correlation between performance and both resource allocation and the efficient use of allocated resources, controlling for socio-economic background throughout.

As pass-fail measures are too binary to accurately reflect the relative performance of schools, we use an overall and mathematical performance index constructed from the last three years' subject results as a measure of school performance. As can be seen from Figure 12, the correlation between the performance index and the pass rate is high, but the graph illustrates the improved discriminatory ability of the index especially at the top end of the scale and thus provides evidence in support of using it.

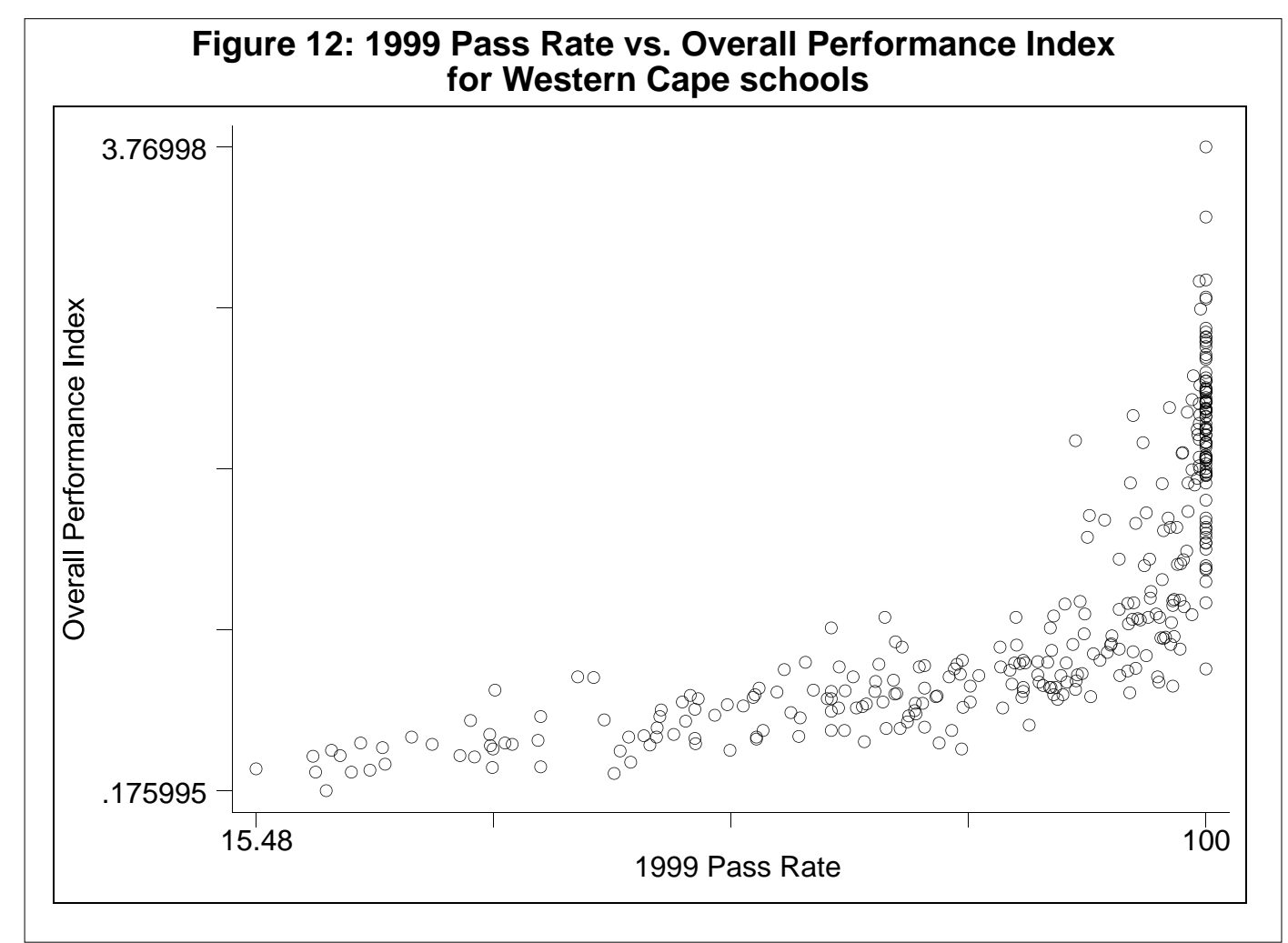


This section will describe four empirical school performance models. Firstly, we estimated two models using the full sample of schools with the overall performance index and the mathematical performance index as the respective dependent variables. After examining the shared characteristics of the five race-based dummies, the sample was divided into three smaller, racebased samples: i) "other" and predominantly white schools; ii) predominantly coloured and black schools and iii) mixed schools. The third group's sample size was inadequate and thus models were only estimated for the first two groups. Due to non-normality of the full sample because of the historical relationship between race, socio-economic background, education spending and educational attainment, the focus will be on the second pair of models that examines causal factors within these smaller race-based samples.

\subsection{Full-sample Models Examining Determinants of Overall and Mathematical Performance in the Western Cape}

Table 4 outlines the first set of models. The model for overall performance includes five of the variables available in the dataset: i) the percentage of school pupils that were white, ii) school fees per learner (also its centred square), iii) a poverty index for the surrounding area (also its centred square), and iv) the pupil-teacher ratio and v) an index measuring the average age of the teachers at the school. The percentage of school pupils that were white, the poverty index, school fees and the average level of qualification of teachers were significant when regressed on the mathematical performance index. In the case of the poverty index, school fees and the average level of teacher qualification both the linear term and the centred square were included in the model.

Table 4: Examining the Determinants of Overall and Mathematical Performance of Schools in the Western Cape

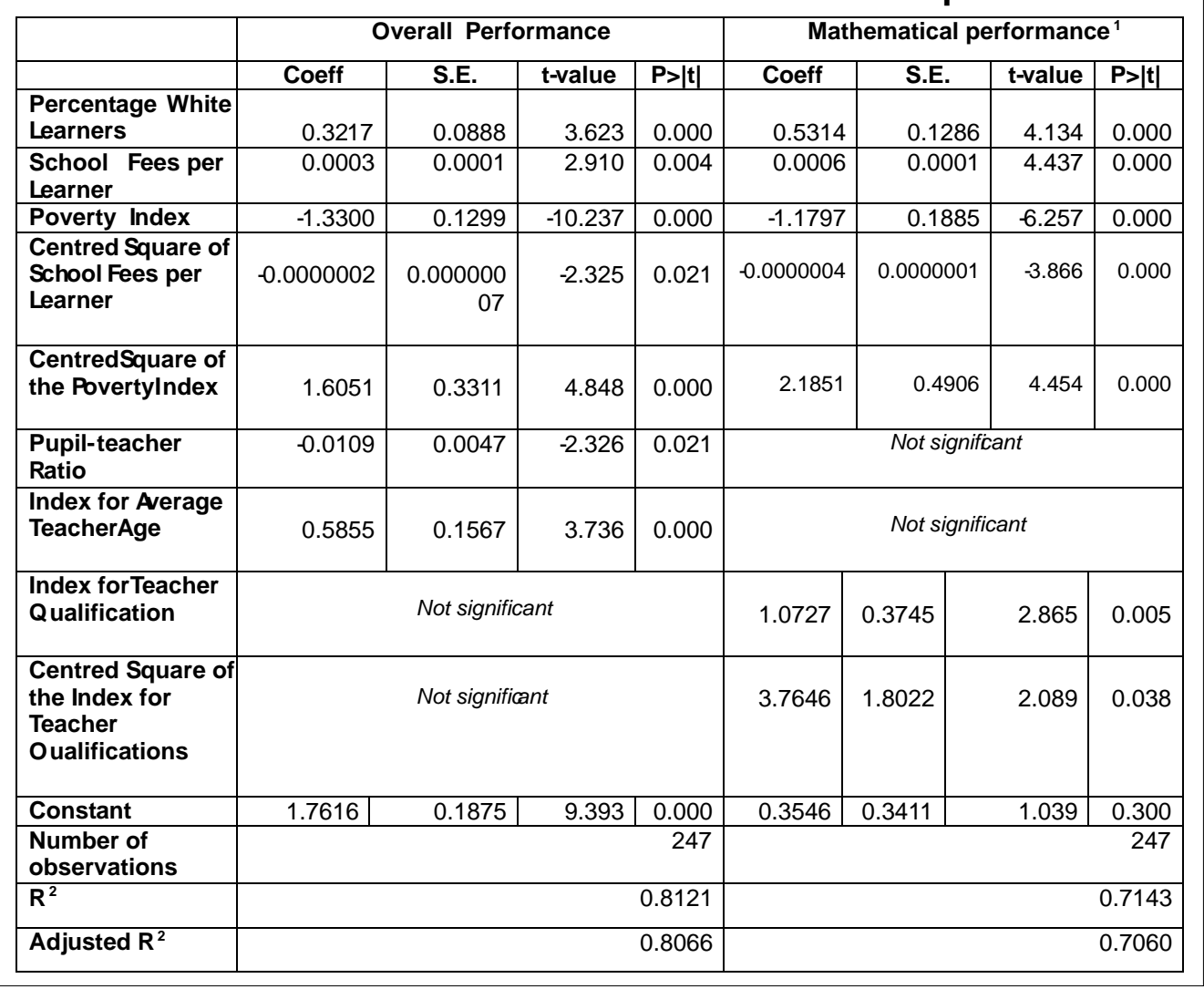


As mentioned previously, the non-normal distribution of the full sample makes it difficult to evaluate the relative impact of resource allocation versus efficient use of resources in a general model. The non-normality of the sampling distribution is a problem because most diagnostic tests presume independent and identically distributed samples.

\subsection{Race-based Models Examining Determinants of Overall Performance in the Western Cape}

According to the model for the predominantly white and "other" schools, the performance of a school is explained by its poverty index, the pupil-teacher ratio and the index for average teacher age. The adjusted R-squared is 0.75 . By multiplying the coefficient by the standard deviation of the variable it is possible to get a rough comparison of the relative impact of the three variables. According to this measure, one standard deviation improvement in the poverty index has the greatest impact $(-0.37)$ followed by the pupil-teacher ratio $(-0.16)$ and the index for the average teacher age (0.15). In the case of "other" and predominantly white schools there is thus evidence that, controlling for socio-economic background, the number of teachers and their average age matters. Other measures of teaching quality and physical resources were not significant.

\begin{tabular}{|c|c|c|c|c|}
\hline \multicolumn{5}{|c|}{$\begin{array}{l}\text { Table 5: Examining the Overall Performance } \\
\text { of "Other" and Predominantly White Schools in the Western Cape }\end{array}$} \\
\hline & Coefficient & S.E. & t-value & $P>|t|$ \\
\hline Poverty Index & -1.6559 & 0.2107 & -7.859 & 0.000 \\
\hline Pupi-teacher Ratio & -0.0314 & 0.0094 & -3.348 & 0.001 \\
\hline Index for Average Teacher Age & 0.9819 & 0.2474 & 3.969 & 0.000 \\
\hline Constant & 2.5119 & 0.2916 & 8.613 & 0.000 \\
\hline Number of Observations & & & & 107 \\
\hline R-squared & & & & 0.7553 \\
\hline Adjusted R-squared & & & & 0.7481 \\
\hline
\end{tabular}

Table 6 summarises a model for the performance of learners from predominantly black and coloured schools. It includes only the poverty index and school fees per pupil as explanatory variables and at 0.31 the coefficient of determination (adjusted R-squared) is dramatically lower than for the predominantly white and "other" schools group. Comparing the two variables by multiplying the coefficients with their standard deviations, the impact of a standard deviation improvement in the poverty index $(-0.12)$ is shown to dominate that of average school fees $(0.06)$.

\begin{tabular}{|c|c|c|c|c|}
\hline \multicolumn{5}{|c|}{$\begin{array}{l}\text { Table 6: Examining the Overall Performance } \\
\text { of Predominantly Black and Coloured Schools in the Western Cape }\end{array}$} \\
\hline & Coefficient & S.E. & t-value & $P>|t|$ \\
\hline School Fees per Learner & 0.0007 & 0.0002 & 3.146 & 0.002 \\
\hline Poverty index & -0.8598 & 0.1393 & -6.171 & 0.000 \\
\hline Constant & 1.2915 & 0.1042 & 12.390 & 0.000 \\
\hline Number of Observations & & & & 121 \\
\hline R-squared & & & & 0.3254 \\
\hline Adjusted R-squared & & & & 0.3140 \\
\hline
\end{tabular}


The resource allocation variables in our dataset fail to contribute substantially to the explanation of black and coloured schools results: the pupil-teacher ratio, the physical index, teacher quantity and the various measures of teacher quality all yielded statistically insignificant coefficients.

Coupled with the low explanatory power of this model, this could point to a substantial role for omitted variables such as the availability of basic teaching resources (e.g. blackboards, textbooks, writing pads, pens and pencils) and also managerial efficiency in the predominantly black and coloured schools. According to these findings, additional investment in teacher quality or quantity is unlikely to yield large improvements in matriculation results for this group before the required complementary resources and/or appropriate managerial skills and incentives structure are in place.

The findings are in line with the results of a comparable study by Crouch and Mabogoane (1998b), who found that matriculation results had a strong and positive correlation with the school's poverty index, a dummy for formerly DET-administered schools and the qualifications of the teachers. Our research would suggest that the qualifications of teachers might not remain a significant determinant if the sample of formerly DET-administered schools is modelled separately.

Crouch and Mabogoane found that weaker, but still significant correlations existed between school performance and what they termed "strongly cognitive resources", i.e. books, the adequacy of media centre material and whether computers were used for teaching. Pupil-teacher ratios, the condition of school buildings and other resources were not significantly correlated with matriculation results.

They attributed the unexplained residual ranging from $20 \%$ to $30 \%$ to differences in the quality of management. Interpreting the DET-administered school dummy as essentially being a dummy for management, they concluded that management might account for around $50 \%$ of the variation in school performance.

\section{Conclusion}

In Section A it was argued that the school system is presently incapable of substantially reducing inequality in the South African labour market because of its inability to reduce inequalities in educational output in any major and systematic way in a relatively short time frame. This is indeed worrying, considering the huge socio-economic inequalities existing in South Africa and the dire need to reduce them.

Section B supports the conclusion from the first section in two ways. Firstly, it was shown for the Western Cape that the large output differentials largely follow past racial patterns. Poor schools with predominantly black and to a lesser extent coloured pupils do much worse than others. Moreover, it was shown that investments to improve teacher quantity and quality are unlikely to offer a viable means of overcoming these shortcomings in education before shortages in complementary teaching materials are addressed and the appropriate management and incentive structures are in place.

This strengthens the case for targeted managerial interventions to reduce inefficiencies in the educational system, whilst weakening the case for resource shifts as the most urgent need. More than resource investments will be required to enable the educational system to make its essential contribution to overcoming labour market inequalities. 


\section{Bibliography}

Anderson, Kermyt G. 2000. Family Structure, Parental Investment, and Educational Outcomes among Black South Africans. Research Report 00-461. Ann Arbor: Population Studies Center, University of Michigan.

Anderson, Kermyt; Case, Anne; \& Lam, David. 2001. Causes and Consequences of Schooling Outcomes in South Africa: Evidence from Survey Data, Research Report 01-490. Ann Arbor: Population Studies Center, University of Michigan.

Archer, S. 1994. State and Market Provision of Education-Selected Issues. EDUPOL report research, Johannesburg: EDUPOL.

Archer, Sean. 1995. Quality and Efficiency Indicators in Education: A Survey. EDUPOL report research, Johannesburg: EDUPOL.

Bhorat, H. \& Leibbrandt, M. 2001. Modelling Vulnerability and Low Earnings in the South African Labour Market. Chapter 3 in Bhorat, Haroon; Leibbrandt, Murray; Maziya, Muzi; Van der Berg, Servaas; \& Woolard, Ingrid (Eds.). 2001. Fighting poverty: Labour Markets and Inequality in South Africa. UCT Press: Cape Town: 107-129.

Card, D. \& Krueger, A.B. 1992. Does School Quality Matter? Returns to Education and the Characteristics of Public Schools in the United States. Journal of Political Economy. Vol. 100 (1): pp. 1-40.

Case, A. \& Deaton, A. 1999. School Inputs and Educational Outcomes in South Africa. Quarterly Journal of Economics CXIV(3): 10471084.

Case, A. \& Yogo, M. 1999. Does School Quality Matter? Returns to Education and the Characteristics of Schools in South Africa. NBER Working Paper W7399. Cambridge, Mass.: National Bureau of Economic Research.

Chamberlain, Doubell. 2001 Earnings Functions, Labour Market Discrimination and Quality of Education in South Africa. Masters Thesis. Stellenbosch: Department of Economics, University of Stellenbosch.

Crouch, Luis \& Mabogoane, T. 1998a. When the Residuals Matter More Than the Coefficients: An Educational Perspective. Studies in Economics and Econometrics, 22(2), pp. 1-14.

Crouch, Luis \& Mabogoane, T. 1998b. No Magic Bullets, Just Tracer Bullets, Mimeo. Pretoria: Department of Education.

Department of Finance. 1998. Medium Term Expenditure Framework Expenditure Review: Education. Pretoria: Government Printer.

Donaldson, Andrew. 1992. Content, Quality and Flexibilty: The Economics of Education System Change. Spotlight 5/92. Johannesburg: South African Institute of Race Relations.

Fiske, Edward B. \& Ladd, Helen F. 2002. Financing Schools in Post Apartheid South Africa: Initial Steps Towards Fiscal Equity. Mimeo. Stanford: Stanford Institute of Public Policy. May.

Hanushek, Eric A. 2002. Publicly Provided Education. NBER Working Paper. Cambridge, Mass.: National Bureau of Economic Research.

Hanushek, E.A. 1996. Measuring Investment in Education. Journal of Economic Perspectives. Vol. 10 (4): pp. 9-30

Hanushek, E.A. 1989. Expenditures, Efficiency, and Equity in Education: The Federal Government's Role. American Economic Review. Vol. 79 (2): pp. 46-51.

Hofmeyr, J.F. \& Lucas, R. 1998. The Rise in Union Wage Premia in South Africa. IED Discussion Paper Series No. 83. Institute for Economic Development: Boston University. 
Kingdon, Geeta \& John Knight. 2002. Quality of Schooling and the Race Gap in Labour Market Outcomes in South Africa. Paper to the Conference of the Centre for the Study of African Economies. Oxford. March.

Krueger, A. 1997. Experimental Estimates of Education Production Functions. NBER Working Paper 6051. Cambridge, Mass.: National Bureau of Economic Research.

Lam, David.1999 Generating Extreme Inequality: Schooling, Earnings, and Intergenerational Transmission of Human Capital in South Africa and Brazil. Research Report 99-439. Ann Arbor: Population Studies Center, University of Michigan.

Lee, J-W \& Barro, R.J. 1997. Schooling Quality in A Cross Section of Countries. NBER Working Paper 6198. Cambridge, Mass.: National Bureau of Economic Research.

Moll, P.G., 1996. The Collapse of Primary Schooling Returns in South Africa 1960 1990. Oxford Bulletin of Economics and Statistics. Vol. 58(1): 185209.

Moll, P.G., 2000. Discrimination is Declining in South Africa But Inequality is Not. Journal for Studies in Economics and Econometrics. Vol. 24(3): 91-108.

Mwabu, Germanu \& Schultz, TP. 1996. Education Returns across Quantiles of the Wage Function: Alternative Explanations for Returns to Education by Race in South Africa. American Economic Review86(2), pp. 335-39.

Pritchett, Lance. 1996. Where Has All the Education Gone? World Bank Policy Research Working Paper1581. World Bank: Washington, D.C.

Schultz, T Paul \& Mwabu, Germano. 2000. Wage Premiums for Education and Location of South African Workers, by Gender and Race. Economic Development and Cultural Change 48(2): 307-334.

Simkins, Charles. 2002. The Jagged Tear: Human Capital, Education, and Aids in South Africa, 2002-2010, Focus, CDE, Johannesburg: Centre for Development and Enterprise.

Taylor, N. 2001. Outcomes, Effort and Values in Schooling. Presentation at the New Millenium Business Conference, 15 May 2001. Available from http://www.jet.org.za

Thomas, D. 1996. Education Across Generations in South Africa. American Economic Review. Vol. 86(2): 330334.

Van der Berg, Servaas. 2001a. An Analysis of the Impact of Resource Inputs and Socio-Economic Status in South African Education Using Multiple Data Sets. Paper to the Conference of the Economic Society of South Africa. Johannesburg. 13-14 September 2001.

Van der Berg, Servaas. 2001b. Resource shifts in South African schools after the political transition, Development Southern Africa 18(4), October 2001: 309-325

Van der Berg, Servaas. 2002. Education, Poverty and Inequality in South Africa, Paper to the Conference of the Centre for the Study of African Economies. Oxford. March.

Van der Berg, Servaas; Wood, Louise \& Le Roux, Neil. 2002. Differentiation in black education. Development Southern Africa 19(2), June: 289-306

Winter, C. 1998. Women Workers in South Africa: Participation, Pay and Prejudice in the Formal Labour Market. Mimeo. World Bank: Washington D.C.APPENDIXA: List of variables in Dataset 1 


\section{Appendix A}

\begin{tabular}{|l|l|l|}
\hline \multicolumn{3}{|l|}{ List of Variables in Dataset 1 } \\
\hline Variable & Description & Year(s) \\
\hline Pass Rate & $\begin{array}{l}\text { Average pass rate of each school over two } \\
\text { years }\end{array}$ & $\begin{array}{l}2000 \\
1999\end{array}$ \\
\hline Pupilteacher Ratio & Pupils per publicly remunerated teacher & 1997 \\
\hline Teacher Salary & $\begin{array}{l}\text { Average salary per publicly remunerated } \\
\text { teacher, a measure of both the qualifications } \\
\text { and experience of teachers }\end{array}$ & 1997 \\
\hline Teacher cost per Pupil & $\begin{array}{l}\text { The cost of remuneration of teachers in a } \\
\text { school expressed relative to the number of } \\
\text { pupils, i.e. combining he previous two } \\
\text { variables }\end{array}$ & 1997 \\
\hline $\begin{array}{l}\text { Race Dummies } \\
\text { (predominantly Black, } \\
\text { Coloured, Indian or White) }\end{array}$ & $\begin{array}{l}\text { Dummies if the dominant group of students } \\
\text { in a school comprise more than 70\% of } \\
\text { pupils }\end{array}$ & 1997 \\
\hline Race Dummy: "Mixed" & $\begin{array}{l}\text { Dummy if no single group comprises more } \\
\text { than 70\% of pupils }\end{array}$ & 1997 \\
\hline Race Dummy "Other" & $\begin{array}{l}\text { Dummy if the racial composition was not } \\
\text { provided, as was quite common amongst } \\
\text { Western Cape schools }\end{array}$ & 1997 \\
\hline Wrote & $\begin{array}{l}\text { The number of pupils who wrote matric in } \\
\text { 1999, used as a weigting factor (the number } \\
\text { who wrote in 2000 was not available) }\end{array}$ & 1999 \\
\hline
\end{tabular}




\section{Appendix B}

\begin{tabular}{|c|c|c|}
\hline \multicolumn{3}{|c|}{ List of Variables in Dataset 2} \\
\hline Variable & Description & Year(s) \\
\hline $\begin{array}{l}\text { Index for Mathematical } \\
\text { erformance }\end{array}$ & $\begin{array}{l}\text { Constructed from three years' mathematics } \\
\text { symbol results for schools (Formula } \\
\text { explained in footnote 10) }\end{array}$ & $\begin{array}{l}2001 \\
2000 \\
1999\end{array}$ \\
\hline $\begin{array}{l}\text { Alternative Index for } \\
\text { Mathematical Performance }\end{array}$ & $\begin{array}{l}\text { Constructed from three years' mathematics } \\
\text { symbol results for schools (Formula given in } \\
\text { footnote 17) }\end{array}$ & $\begin{array}{l}2001 \\
2000 \\
1999\end{array}$ \\
\hline Index for Overall Performance & $\begin{array}{l}\text { Constructed from three years' subject } \\
\text { symbol results for schoolsfformula } \\
\text { explained in footnote 10) }\end{array}$ & $\begin{array}{l}2001 \\
2000 \\
1999 \\
\end{array}$ \\
\hline School Fees per Learner & $\begin{array}{l}\text { Collected income of school divided by the } \\
\text { number of learners }\end{array}$ & 1997 \\
\hline Poverty Index & $\begin{array}{l}\text { Poverty index of area around school (from } \\
\text { Norms and Standards) }\end{array}$ & 2000 \\
\hline Physical Index & Physical conditon of the school building & 2000 \\
\hline Index for Teacher Qualification & $\begin{array}{l}\text { Index calculated as } \frac{x-\min }{\max -\min } \text {, using } \\
\text { average REQV of teachers. According to } \\
\text { Budget Brief } 52 \text { one needs a REQV of } 13 \text { to } \\
\text { be a qualified teacher. A REQV of B } \\
\text { represents Matric andthree years of training. }\end{array}$ & 2000 \\
\hline Teaching Experience & Average years of teaching experience & 2000 \\
\hline $\begin{array}{l}\text { Index for Average Age of } \\
\text { Teachers }\end{array}$ & $\begin{array}{l}\text { Index calculated as } \frac{x-\min }{\max -\min } \text {, using } \\
\text { average age of teachers in school }\end{array}$ & 2000 \\
\hline Cost per Teacher & $\begin{array}{l}\text { Total teacher salarés divided by number of } \\
\text { teachers }\end{array}$ & 1997 \\
\hline Pupilteacher Ratio & $\begin{array}{l}\text { Number of pupils divided by number of } \\
\text { teachers in the school }\end{array}$ & 2000 \\
\hline Township Dummy & & 2000 \\
\hline $\begin{array}{l}\text { Percentage of Black Pupils in } \\
\text { School }\end{array}$ & Percentage of school's pupils black & 1997 \\
\hline $\begin{array}{l}\text { Percentage of Coloured Pupils } \\
\text { in School }\end{array}$ & Percentage of school's pupils coloured & 1997 \\
\hline $\begin{array}{l}\text { Percentage of White Pupils in } \\
\text { School }\end{array}$ & Percentage of School's pupils white & 1997 \\
\hline
\end{tabular}

